\title{
PIV を用いた流れの可視化と風圧の同時測定による 細長い三次元柱周りの流れと空気力に関する実験的研究 \\ EXPERIMENTAL STUDY ON AERODYNAMIC FORCE AND WIND FLOW AROUND A THREE-DIMENSIONAL SLENDER CYLINDER BY SYNCHRONOUS WIND PRESSURE MEASUREMENTS WITH PIV
}

\author{
吉川清 峰*1, 奥田泰雄 ${ }^{* 2}$, 伊藤真二*3, 大橋征 幹*4, 佐々木 康人*5 \\ Kiyomine YOSHIKAWA, Yasuo OKUDA, Shinii ITO, \\ Masamiki OHASHI and Yasuhito SASAKI
}

\begin{abstract}
The wind flows around a three-dimensional slender cylinder model and the wind pressures acting on it were measured synchronously by Particle Image Velocimetry (PIV) and simultaneous multi-pressure measurements. Symmetrical mean flow distributions were obtained from piles of instantaneous flow distributions. The relations between the separated shear layers and the wind pressures on the side of the model were shown by synchronous records between instantaneous flows and wind pressures. The correlations between the perpendicular components (V components) of the flow around the model and the lift forces on it were highest. The correlation on the centerline in the wake also had spatial periodic fluctuations like a sine wave. It can be considered that the spatial periodic fluctuations in the correlation were caused by the vortex shedding from the model, because of a high relationship between the spatial period of the fluctuations and the reciprocal Strouhal number.
\end{abstract}

Keywords: PIV, Wind pressure measurement, Synchronous measurement, Three-dimensional cylinder, Instantaneous flow, Lift force, Correlation PIV, 風圧実験, 同時測定, 三次元柱, 瞬間流れ, 揚力, 相関

1.はじめに

超高層建築物や橋梁の主塔のようなアスペクト比の大きな構造物 は、耐風設計において、その空力特性の把握が特に重要である。こ れらの構造物のような鈍い物体の空力特性は、剥離せん断層や後流 のカルマン渦の挙動と密接に関連していることが知られており、物 体の隅角部に隅切りを施したりするのも、剥離せん断層や後流の挙 動を制御し、空気力を低減させるための工夫のひとつである。言い 換えれば、後流の挙動をモデル化することができれば、その空力特 性を耐風設計上有利な方向人導くことも期待できる。しかし、鈍い 物体周りの流れの構造と後流に伴う空気力の対応関係が、具体的に 明らかになっているわけではない。また耐風設計において数值流体 解析も応用されはじめているが、その検証には実験結果を参照する 必要があり、物体周りの流れの構造と空気力の関倸を実験的に明ら かにする意義は大きい。

これまでにも、建築物や土木構造物を模した柱状の鈍い物体周り の流れと空気力の関係については、様々な手法を用いて研究が進め られてきている。溝田ら ${ }^{1), 2}$ は、タンデム型熱線流速計プローブによ り一様流内の二次元矩形柱周りの流れを測定し、伴流淀み点位置と 背圧係数や抗力係数との関係を明らかにし、また変動揚力と非定常
流速の位相関係から非定常流線を示した。田村ら ${ }^{3}$ は、三次元数値流 体解析により二次元矩形柱周りの流れの構造を分析し、剥離せん断 層と矩形柱側面の距離の周期的変化が揚力の発生に寄与するとして いる。二次元柱の空気力特性については、西村ら ${ }^{4), 5,6), 77}$ や野田ら $^{8)}$ が 詳細に調べている。田村ら ${ }^{99,10}$ は、角柱に隅切や隅丸を施した二次元 および三次元の角柱を対象に、空気力については風洞実験、周辺流 れについては数值流体解析の結果を用いて、その効果を確認してい る。流れの可視化によって流れと空気力の関係を調べた実験も数多 くある。岡島 ${ }^{11)}$ は、風洞実験ではスモークワイヤー法、水槽実験で はアルミ粉末法と電解沈殿法を併用して、Re 数や辺長比によって矩 形柱の St 数や背圧係数が複雑に変化することを見いだした。また西 村ら $\left.{ }^{12}\right)$ は、スモークワイヤー法による流れの可視化と風圧測定を同 時に行い、亜臨界域での円柱周りの流れの変動から、揚力変動の発 生機構について記述している。谷池ら ${ }^{13)}$ と奥田ら ${ }^{14), 15), 16)}$ は、ドライ アイスのミストや四塩化チタンを用いた流れの可視化と風圧測定を 行って、三次元角柱周りの渦形成から放出の過程を定性的に述べて いる。.河村ら ${ }^{17}$ は、二次元角柱を対象に、タフトを用いた可視化と 数值流体解析、さらに天秤による空気力の測定と表面圧力の測定を 行っている。
*1 飛島建設技術研究所

*2 建築研究所 '工博

*3 湭池組技術研究所

*4 国土交通省国土技術政策総合研究所

*5 フジタ技術センター
Research Institute of Technology, Tobishima Corporation Building Research Institute, Dr. Eng.

Research Institute of Technology, Konoike Construction

National Institute for Land and Infrastructure Management, MLIT

Technology Development Division, Fujita Corporation 


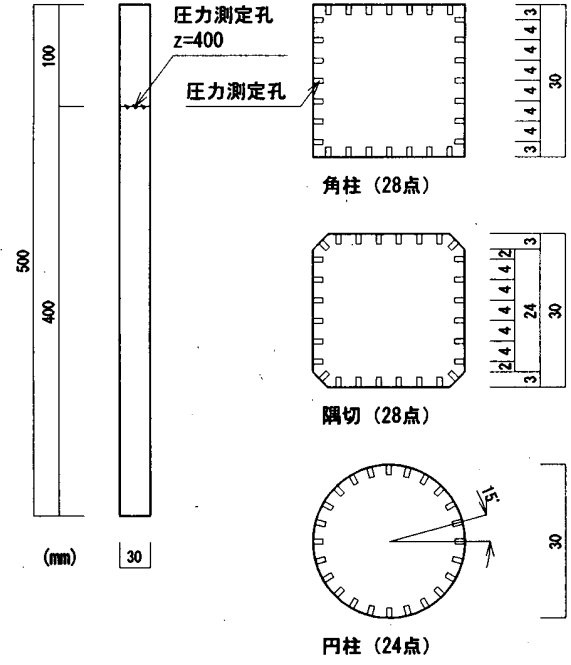

図 1 実験模型

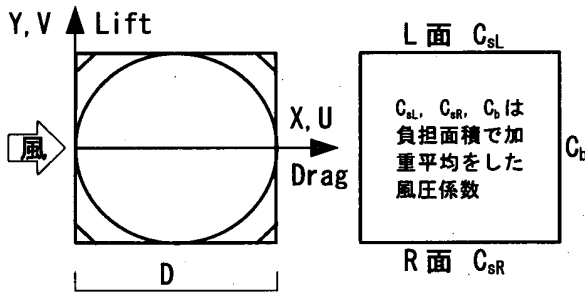

図 2 座標系

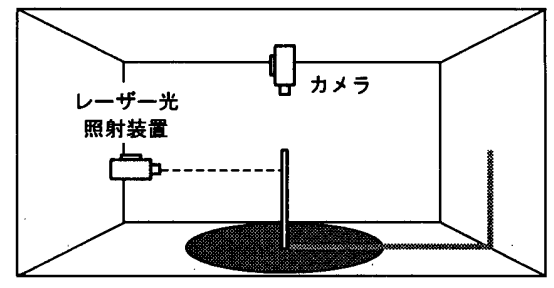

図 3 風洞風上から見た実験模式図

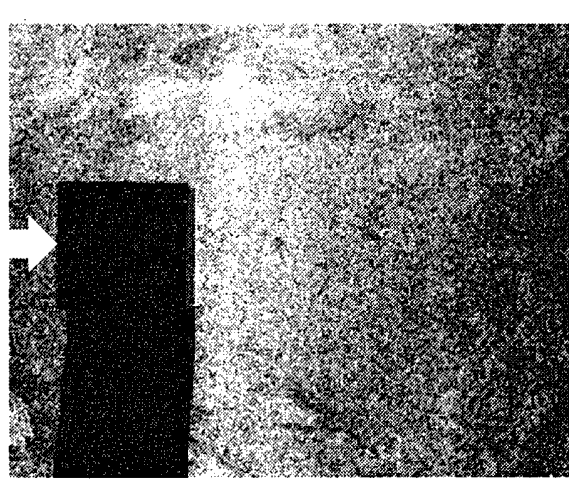

図 4 粒子画像
表 1 PIV 諸元

\begin{tabular}{|c|c|}
\hline 光源 & Nd:YAG レーザー $50 \mathrm{mmJ} 15 \mathrm{~Hz}$ \\
\hline 画像記録手法 & 2フレーム/単一露光 \\
\hline 照明パルス持続時間 & $0.01 \mu \mathrm{s}$ \\
\hline 照明パルス時間間隔 & $50 \mu \mathrm{s}$ \\
\hline カメラ & DANTEC HiSence Camera 80C60 \\
\hline カメラ解像度 & 1280pixel x 1024pixel, 12bit \\
\hline サンプリンク周波数 & $2 \mathrm{~Hz}$ \\
\hline 測定領域 & $137.5 \mathrm{~mm} \times 110.0 \mathrm{~mm}$ \\
\hline 桧查領域 & 32 pixel $\times 32$ pixel $(3.4 \mathrm{~mm} \times 3.4 \mathrm{~mm})$ \\
\hline オーバーラップ & 無 \\
\hline トレーサー粒子 & SAFEX@ Normal Power Mix \\
\hline
\end{tabular}

表 2 測定条件

\begin{tabular}{l|c|c|c|c}
\hline \multirow{2}{*}{} & \multicolumn{2}{|c|}{ 瞬間値 } & \multicolumn{2}{c}{ 平均値 } \\
\cline { 2 - 5 } & 風圧 & PIV & 風圧 & PIV \\
\hline \hline $\begin{array}{l}\text { サンプリンクク } \\
\text { 周波数 }\end{array}$ & $1000 \mathrm{~Hz}$ & $2 \mathrm{~Hz}$ & $1000 \mathrm{~Hz}$ & $2 \mathrm{~Hz}$ \\
\hline $\begin{array}{l}\text { サンプリング } \\
\text { 時間 }\end{array}$ & \multicolumn{2}{|c|}{$8.192 \mathrm{~s}$} & $8.192 \mathrm{~s} \times 5$ & $180 \mathrm{~s}$ \\
\hline サンプル数 & 8192 & 最大 16 & $8192 \times 5$ & 360 \\
\hline
\end{tabular}

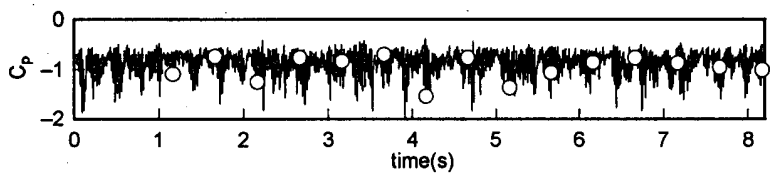

図 5 サンプリングの一例

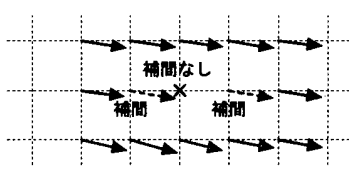

図 6 流速ベクトルの補間
このように物体周りの流れと空気力の関係については、流速測定、 風圧測定、空気力測定、数值流体解析、流れの可視化などの様々な 手法によって明らかにされつつある。しかし流れ全体や空気力との 測定が同時でなかったり、定性的な流れの把握であったり、高度な 条件設定が要求される数值流体解析であったりと、それぞれに一長 一短があり、それらの手法が相補う形で研究が進められてきた。そ のためこれまでは、定量的な瞬時の流れの全体構造と、それと同時 刻の空気力を実験的に得ることができず、物体周りの流れと空気力 の関係の解明には未だ不十分な点も多い。

一方、近年コンピュータの処理能力の向上やその他ハードウェア の進歩と共に、粒子画像流速測定法 (Particle Image Velocimetry, 以 下 PIV という）が普及してきた ${ }^{18)}$ 。PIVよりさらに空間分解能の高 いPTV(Particle Tracking Velocimetry)と呼ばれる計測手法も実用化 の域にある例えば19)。さらに現在、時間分解能を高めた高速度 PIV や、 二次元断面内の面外速度を測定（3 成分化）するステレオ PIV、三 次元の流速を測定する三次元 PTVも開発が進められている例立は20),21)。

これら PIVによる測定の利点は、空間分解能が高く、瞬時の流れ の構造を定量的に捉えることが可能であるといった点等 22 にあり、 また熱線流速計のようにプローブを流れの中に設置することがない ため、測定対象付近の流れの構造を乱すこともない。そのため現在、 有効な流体測定法としてこれらの PIV を用いた研究が進められてお り刚えば19)、筆者ら ${ }^{23)}$ も塔状構造物を対象とした PIV と数值計算の比 較を行っている。また流れと空気力という観点からも、筆者ら $\left.{ }^{24)} 29\right)$ は、立方体や細長い柱周りの流れの測定を行い、同時に行った多点 風圧測定との比較から、物体周りの流れと物体に作用する空気力に ついて研究を行ってきた。
以上のような既往の研究や近年の技術の進歩を踏まえた上で、本 研究では、流れと空気力の関係を実験的に明らかにする目的で、細 長い 3 種類の柱状模型を作製し、2 種類の気流を用いて、PIV によ る周辺流れの測定と多点風圧測定を同時に行った。2つの測定結果 から、平均流れと平均風圧、瞬間流れと瞬間風圧、また流れと空気 力の相関を検討することにより、物体周りの流れと物体に作用する 空気力の関倸について述べる。実験では、二次元流れにおける関係 の解明を試みたが、結果的に三次元流れについての議論としている。

\section{2. 実験概要}

風洞実験は、独立行政法人建築研究所内の回流型乱流境界層風洞 （測定胴長さ $25.0 \mathrm{~m} \times$ 幅 $3.0 \mathrm{~m} \times$ 高さ $2.5 \mathrm{~m}$ ）にて実施した。

通常二次元的な流れの把握を目的とする実験では、流れの二次元 性が損なわれないような配慮が必要であるが、本研究ではカメラ撮 影が必要であるため、模型の両端に端板などを設けることが難しい。 そこで実験模型は、図 1 に示すような一辺が $30 \mathrm{~mm}$ 、高さが $500 \mathrm{~mm}$ の、アスペクト比 16.7 の形状とした。模型は 3 体作製し、一辺が $30 \mathrm{~mm}$ の正方形角柱（以下角柱）、一辺が $30 \mathrm{~mm}$ の角柱の各頂点に $3 \mathrm{~mm}$ の隅切りを施した隅切り角柱（以下隅切）、さらに直径が $30 \mathrm{~mm}$ の 円柱である。いずれも $400 \mathrm{~mm}$ の高さに角柱 28 点、隅切 28 点、円 柱 24 点の圧力測定孔を設けた。この圧力測定孔高さを基準高さ $\mathrm{H}$ とし、流れの測定と風圧測定はこの高さにて行う。PIV のカメラに よる撮影は、測定高さを自由端から十分に離すと、模型の見込みに よって模型近傍まで測定することができない。一方田村 ${ }^{30}$ は、アス ペクト比の大きい円柱の場合、二次元的な流れになっていると思わ れるのは、自由端から 3D〜4D 以上としている。この測定高さはこ 


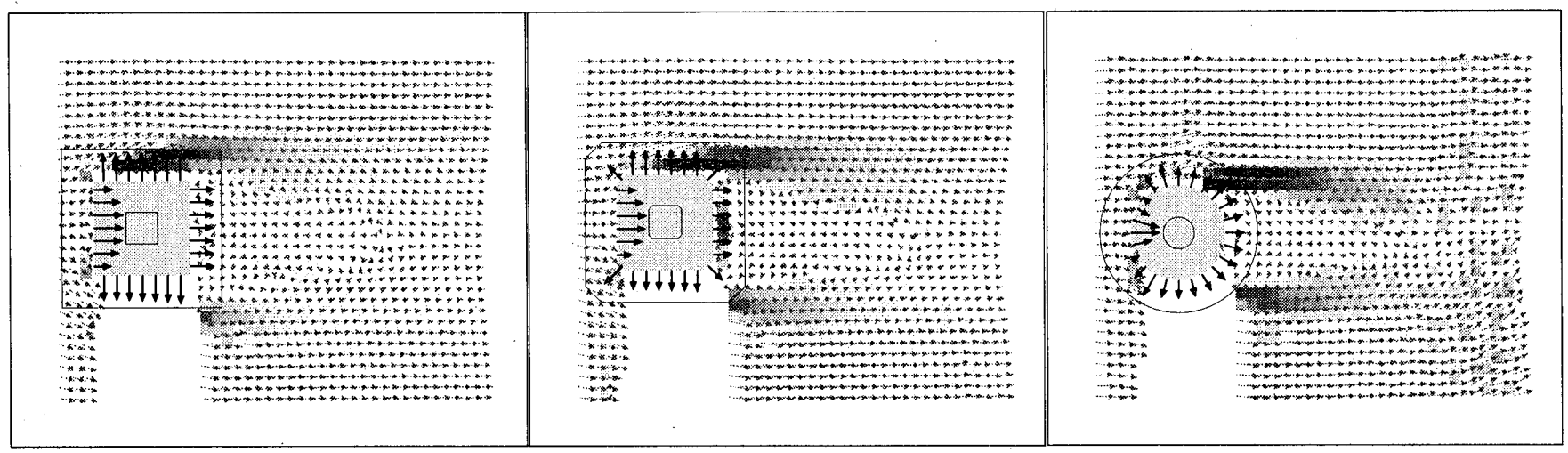

図 7a 角柱一様流

図 7c 隅切一様流

図 7e 円柱一様流

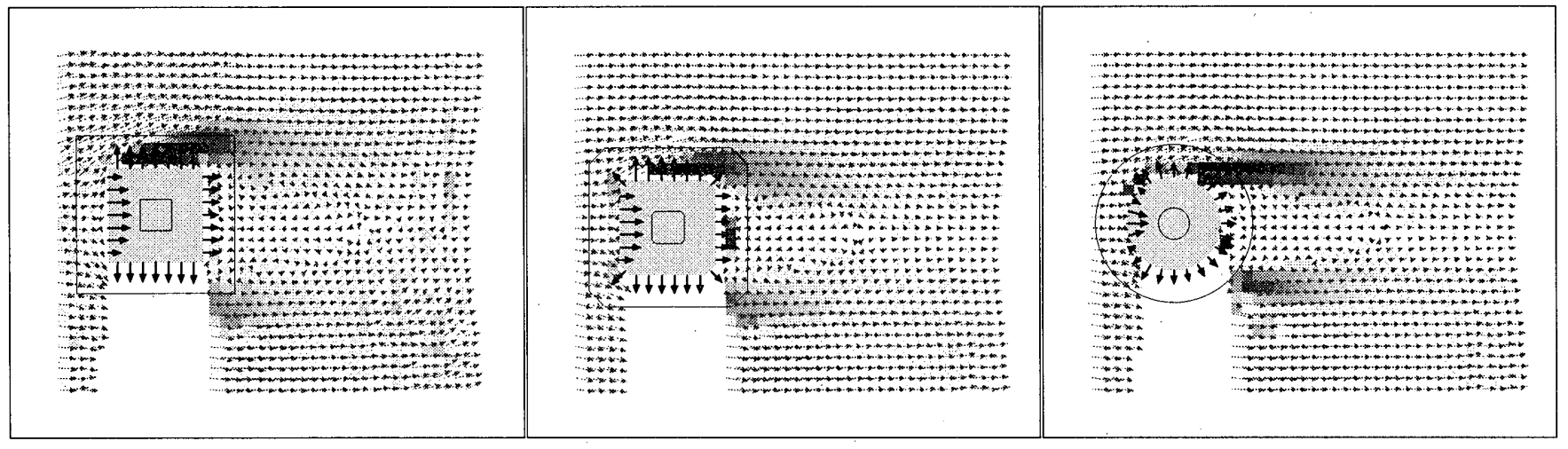

図 7b 角柱乱流

図 7d 隅切乱流

図 7f 円柱乱流

図 7 平均流速ベクトル (平均渦度) - 平均風圧係数分布

れらを勘案して決められた。実験気流は $\mathrm{I}_{\mathrm{H}}=1.0 \%$ の一梯流と $\mathrm{I}_{\mathrm{H}}=6.0 \%$ の乱流を用いた。基淮風速 $\mathrm{U}_{\mathrm{H}}$ はどちらの気流も約 $12 \mathrm{~m} / \mathrm{s}$ で、Re 数 は概ね $2.5 \times 10^{4}$ である。実験は模型が 3 種、気流が 2 種の、計 6 ケ 一スとなる。

また図 2 に示すように座標軸を定め、模型最前面中央から風の主 流方向に X 軸、主流方向から見て左方向に $\mathrm{Y}$ 軸と寸る。また $\mathrm{X}$ 軸, $\mathrm{Y}$ 軸方向の速度をそれぞれ U, V とする。風向は変化させないので、 抗力，揚力はそれぞれ X 軸，Y 軸方向の力である。

この実験の模式図を図 3 に示す。PIV の流れの被写体となるトレ 一サー粒子は、粒径 1 $6 \mu \mathrm{m}$ 程度の液滴で、風洞風上の床面で熱に よって気化させ、送風機を回した状態で十分な時間をおくことによ り、風洞内にトレーサー粒子を充満させておく。PIV の測定は、模 型の圧力測定孔部分に模型側面からレーザー光を照射し、カメラを 模型の真上に設置して平面的な流れを撮影した。このとき模型自身 の影となる部分については、粒子画像を得ることができず、流速べ クトルを求めることができない。この PIVにより撮影した粒子画像 の一例を図 4 に示す。PIV は DANTEC 社製 PIV システム(FlowMap, FlowManager) ${ }^{31)}$ を使用した。諸元を表 1 に示す。全測定領域と 1 検 查領域の関係から、X 軸方向 40 点、Y 軸方向 32 点の、計 1280 点の 流速べクトルを出力する。なお本システムは、2 枚の粒子画像の濃 度分布パターンを解析する相互相関法 PIV である。事前にX 型熱線 流速計や LDV との比較により、平均流れについて精度の確認を行 い良い一致を得ている。

模型周りの流れはこのPIVにより、また模型に作用する風圧は多 点風圧測定装置により測定した。表 2 に測定条件を示す。瞬間値の 場合は、多点風圧測定はサンプリング周波数 $1000 \mathrm{~Hz}$ 、サンプリング
時間は約 8 秒とした。PIV カメラからの同期信号を風圧実験からの 圧力信号と同じ多点風圧測定装置に入力することにより、両者の同 期を図った。つまり、PIVカメラからの同期信号も $1000 \mathrm{~Hz}$ でサンプ リングされている。しかし PIV の撮影のサンプリング周波数は $2 \mathrm{~Hz}$ であるので、図 5 に示すように、PIVのサンプル数は最大 16 である。 この実験を 5 回行った。PIV からの同期信号が記録された時刻の風 圧測定結果を、同時刻の記録として扱った。この同時刻として扱っ た風圧測定記録とその前後の記録を比較して、大きな差異がないこ とを確認している。平均風圧は上記の $8192 \times 5$ 回の記録を平均した ものとした。平均流れは、上記とは別に、180 秒間に得られる 360 の瞬間流速ベクトルの記録を平均した。基準静圧は風洞風上の高さ $1 \mathrm{~m}$ に設置したピトー管により測定した。また導圧チューブの伝達特 性の補正を行った。

PIVは極めて短い時間間隔（表 1 より $50 \mu \mathrm{s}$ ) で撮影された 2 枚の 粒子画像の相互相関から流速ベクトルを求めるが、トレーサー粒子 の濃度分布の抽出や相関の計算ができずに、過誤ベクトルを出力す る場合がある。そこで図 6 に示すように、任意の点の流速ベクトル が過誤ベクトルと評価された場合、その点の周囲 3 点以上が有意で あれば線形補間を行った。周囲の有意な点が 2 点以下の時には欠測 とし、その後の解析からは除外した。

\section{3. 実験結果}

\section{1 風圧実験}

風圧実験の結果を表 3 に示す。風力倸数は風圧保数から求めてい る。す心゙ての風力係数で角柱, 隅切, 円柱の順に小さくなり、平均 抗力係数 $\mathrm{C}_{\mathrm{D}}$ は、一样流の方が乱流より大きく、变動抗力係数 $\mathrm{C}_{\mathrm{D}}{ }^{\prime}$ と 
表 3 風圧実験の結果

\begin{tabular}{c|c|c|c|c|c|c}
\hline \multirow{2}{*}{} & \multicolumn{2}{|c|}{ 角柱 } & \multicolumn{2}{c|}{ 隅切 } & \multicolumn{2}{c}{ 円柱 } \\
\cline { 2 - 7 } & 一様流 & 乱流 & 一様流 & 乱流 & 一様流 & 乱流 \\
\hline \hline $\mathrm{C}_{\mathrm{D}}$ & 1.534 & 1.159 & 1.085 & 0.857 & 0.789 & 0.593 \\
\hline $\mathrm{C}_{\mathrm{D}^{\prime}}$ & 0.149 & 0.193 & 0.087 & 0.144 & 0.062 & 0.092 \\
\hline $\mathrm{C}_{\mathrm{L}^{\prime}}$ & 0.372 & 0.397 & 0.211 & 0.269 & 0.075 & 0.092 \\
\hline $\mathrm{St}$ & 0.106 & 0.102 & 0.124 & 0.122 & 0.161 & 0.158 \\
\hline
\end{tabular}

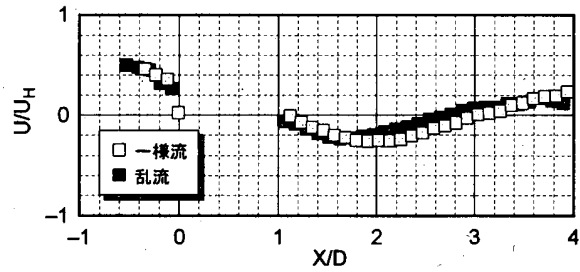

图 $8 \mathrm{X}$ 座標と U 成分の関俰（角柱）

表 4 同時刻の記録数

\begin{tabular}{r|r|r|r|r|r}
\hline \multicolumn{2}{c|}{ 角柱 } & \multicolumn{2}{c|}{ 隅切 } & \multicolumn{2}{c}{ 円柱 } \\
\hline 一栚流 & 乱流 & 一様流 & 乱流 & 一様流 & \multicolumn{1}{|c}{ 乱流 } \\
\hline 73 & 61 & 74 & 64 & 68 & 71 \\
\hline
\end{tabular}

表 5 条件抽出された風圧係数

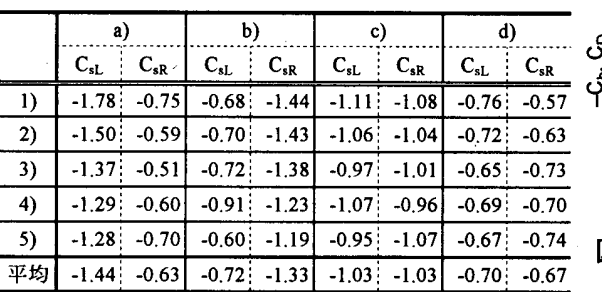

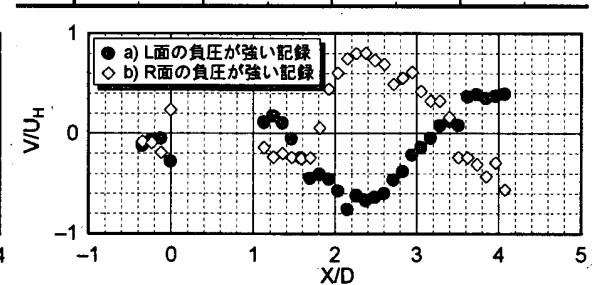

図 $12 \mathrm{X}$ 座標と V 成分の関係

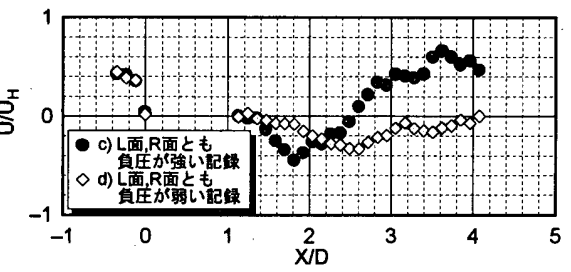

図 $13 \mathrm{X}$ 座標とU成分の関係

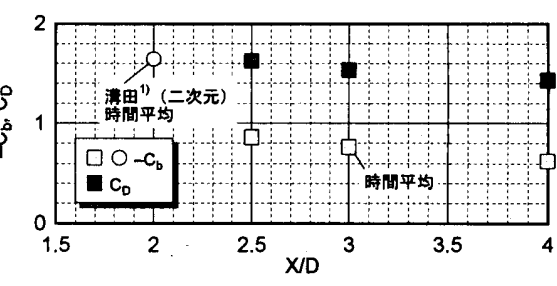

图 14 後方淀み点と背圧・抗力係数の関係

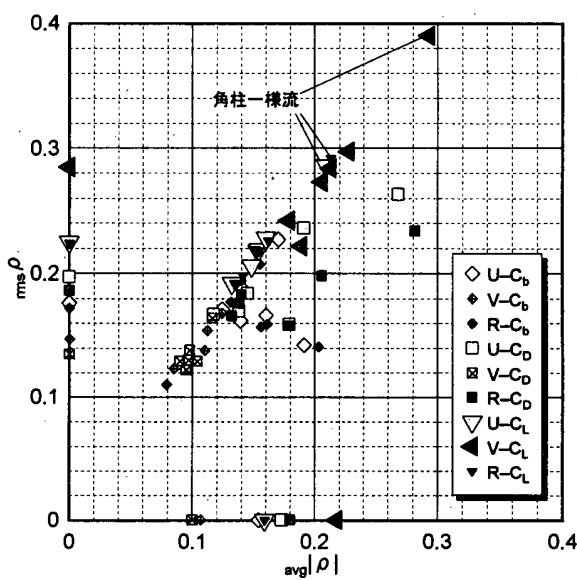

図 15 相関俰数の絶対値の平均值と相関係数 の標準偏差
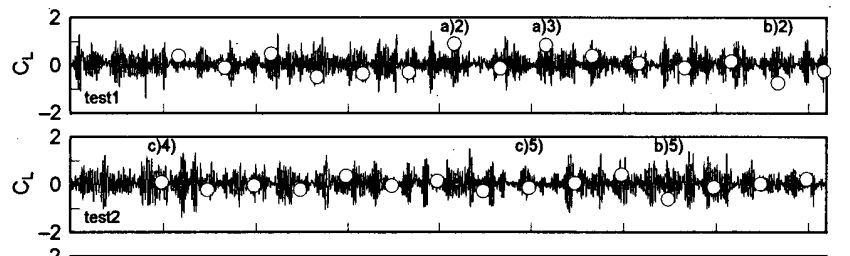
$\int_{-2}^{2} \int_{\text {test3 }}^{2}$
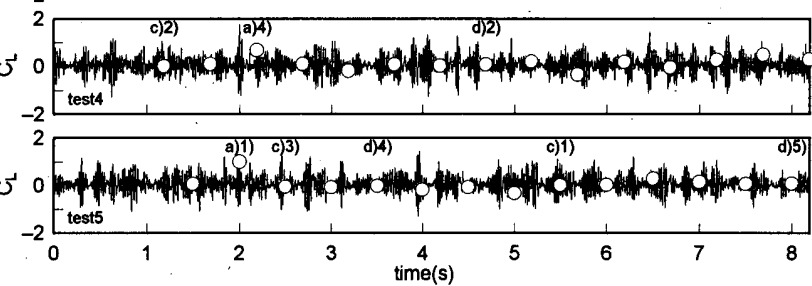

図 9 揚力の時刻歴波形と PIV の測定時刻
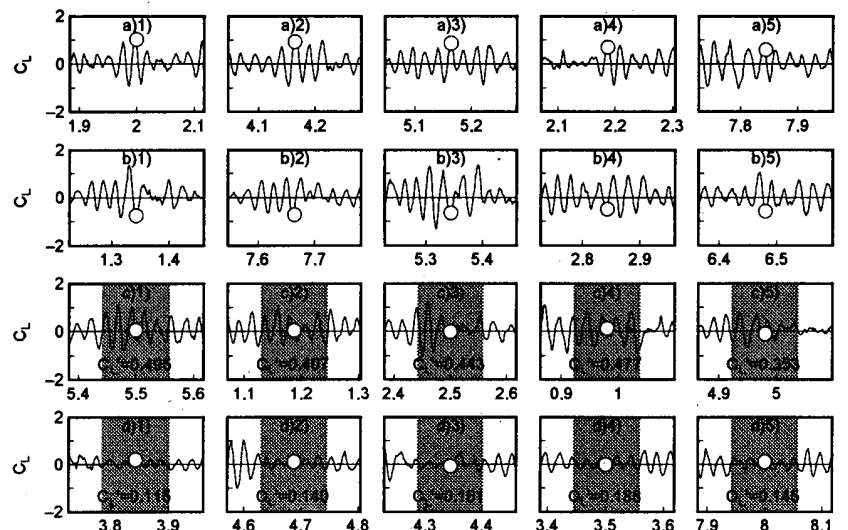

図 10 条件抽出された測定時刻近傍の揚力の時刻歷波形

変動揚力係数 $\mathrm{C}_{\mathrm{L}}$ 'は乱流の方が一様流より大きい。また変動揚力のパ ワースペクトル密度より求めた St 数は、角柱, 隅切, 円柱の順に大 きな値となっている。しかし二次元柱について行われた既往の実験
結果 4 (),5),8,99) と比較すると、二次元流れの性状は示していない。

\section{2 平均流れと平均風圧}

6 ケースの実験について、時間平均の、流速ベクトル, 渦度, 風 圧係数を求めた。図 7a〜7fに平均流速べクトルー平均風圧係数分布 を示す。また流速べクトルから求めた渦度も色の漂淡で示している。 模型内外の細実線はそれぞれ風圧倸数 +1.0 と-1.0 を示している。

PIV のサンプリング周波数は $2 \mathrm{~Hz}$ であり、渦放出周波数（角柱一 様流で 42.8Hz）に比較して大幅に不足しているが、360 の瞬間流速 ベクトルをアンサンブル平均することによって得られた流速べクト ルと渦度の分布は、ほぼ左右対称に現れ、平均流れ場が求められて いると考えられる。渦度の分布から角柱, 隅切, 円柱と角が滑らか になるに従って後流幅が狭くなっていることが確認できる。一様流 と乱流を比較すると、どの形状を見ても、一様流の方が平均風圧係 数の絶対值が大きくなっており、流れの特徴がより顕著に現れてい ると言える。しかし図 7 の流速べクトル分布や渦度分布からは、二 様流と乱流の明確な差異は認められない。

図 7a，図 7b について、X 軸上で見た模型前面からの距離と流速 ベクトルの U 成分の関係を図 8 に示す。接近流の流速が模型の直前 で減少し、模型の背後では逆流の部分が存在した後、再び主流方向 の流れとなっている。模型の背後で $\mathrm{U} / \mathrm{U}_{\mathrm{H}}$ が負から正に符号が変わ る点を後方淀み点と見なすと、一様流中の角柱では後方淀み点は $\mathrm{X} / \mathrm{D}=3.0$ で、背圧係数は $\mathrm{C}_{\mathrm{b}}=-0.76$ である。また乱流中の角柱では後 方淀み点は $\mathrm{X} / \mathrm{D}=2.8$ で、 $\mathrm{C}_{\mathrm{b}}=-0.55$ である。Laneville et al. ${ }^{32)}$ は、辺長 比 $\mathrm{D} / \mathrm{B}=1$ 程度の二次元角柱周りの流れは、一様流より乱流の方が後 流域が長くなり背面の負圧が弱くなるとしているが、本研究の後方 淀み点は乱流の方が若干近い。これは気流の三次元性が現れている ためと考えられる。

\section{3 瞬間流九と瞬間風圧}

5 回の実験により、同時刻の流速ベクトル分布と風圧分布が得ら 


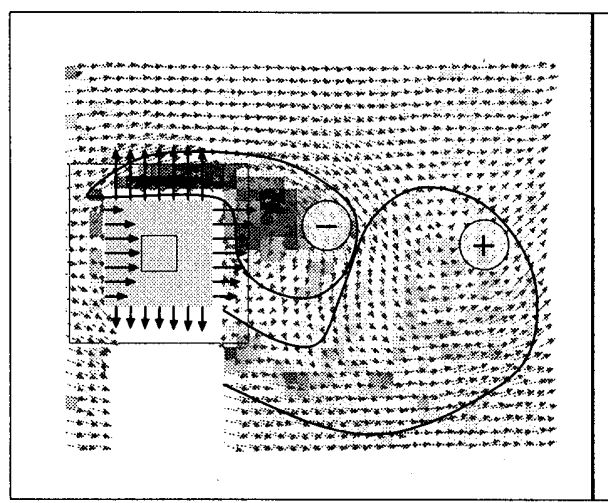

図 11a L 面の負圧が強い記録

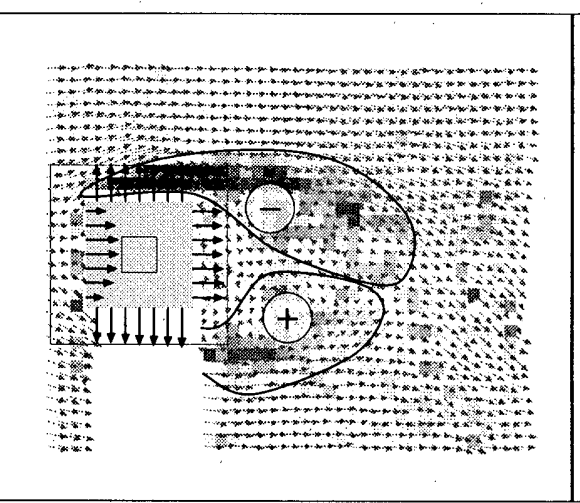

図 11c L 面， R 面とも負圧が強い記録

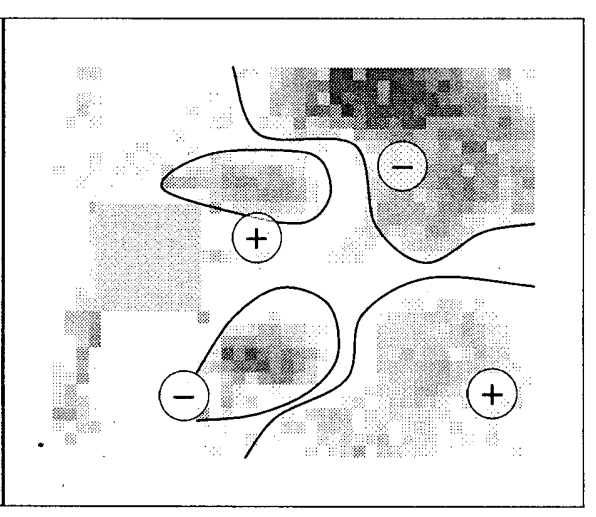

図 16 U 成分と揚力の相関係数

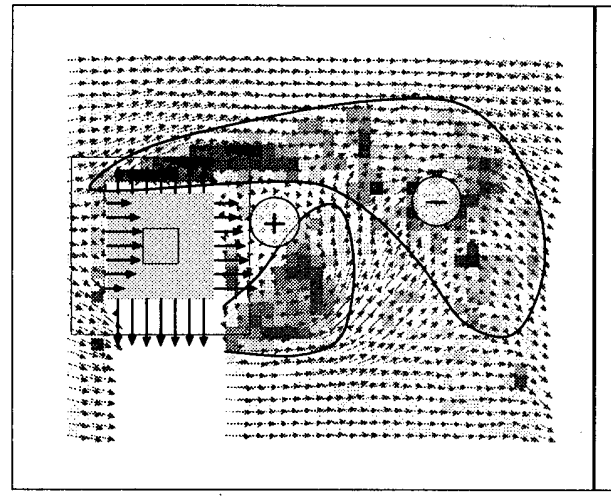

図 11b R 面の負圧が強い記録

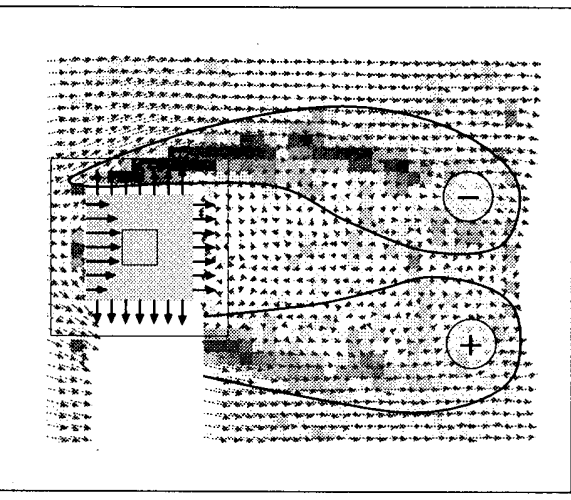

図 11d L 面， R 面とも負圧が弱い記録

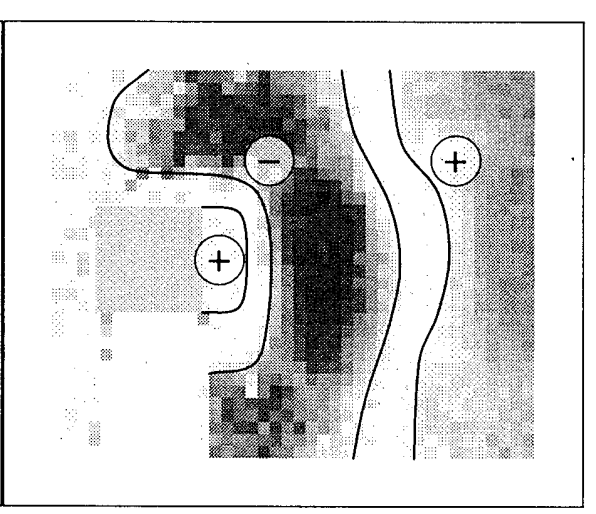

図 $17 \mathrm{~V}$ 成分と揚力の相関係数

図 11 流速ベクトル（渦度）一風圧係数分布

れている記録数は表 4 に示寸通りである。ここでは風圧係数の絶対 值も大きく、強いカルマン渦が発生しやすい、一様流中の角柱につ いての検討を行う。瞬間の流れの構造と空気力の関係を調べるため に、73 の同時刻の記録から、模型側面の風圧係数 $\mathrm{C}_{\mathrm{sL}}$ と $\mathrm{C}_{\mathrm{sR}}$ (図 2 参照）に着目して、a)〜d)の条件で記録の抽出を行った。
a) $\min \left(\mathrm{C}_{\mathrm{sL}}\right)$
$\mathrm{L}$ 面の負圧が強い記録
b) $\min \left(\mathrm{C}_{\mathrm{sR}}\right)$
$\mathrm{R}$ 面の負圧が強い記録
c) $\min \left(\max \left(\mathrm{C}_{\mathrm{sL}}, \mathrm{C}_{\mathrm{sR}}\right)\right)$
$\mathrm{L}$ 面， $\mathrm{R}$ 面とも負圧が強い記録
d) $\max \left(\mathrm{C}_{\mathrm{sL}}+\mathrm{C}_{\mathrm{sR}}\right)$
$\mathrm{L}$ 面, $\mathrm{R}$ 面とも負圧が弱い記録

上記のそれぞれの条件で、上位から順に 5 記録ずつ抽出した。 抽出した記録を表 5 に示す。最左列の括弧付きの数字は抽出順位 を示している。抽出されたそれぞれの記録が時刻歷上でどのような 位相にあるかを確認するために、図 9 に 5 回の実験の揚力の時刻歷 波形と、PIV の測定時刻を示す。また条件抽出をした測定時刻近傍 （St 数の逆数から求めた渦放出周期の 10 周期分）の揚力の時刻歷 波形を図 10 に示す。a)，b)については、揚力変動のそれぞれ正負の ピークに近い位相を示している。c), d)については、測定時刻近傍 (図中網掛け, 同 5 周期分) の変動揚力係数 $\mathrm{C}_{\mathrm{L}}$ 'を比較すると、全時 間平均の 0.372 (表 3）と比較して明らかな差があり、c), d)はそれ ぞれ、揚力変動の大振幅または小振幅中のゼロクロスであることが 解る。

このような 4 つの条件時の物理的な現象を浮き立たせるために、 抽出したそれぞれ 5 つの記録のアンサンブル平均を行った。図 11a 〜11 に、a) d ) でのアンサンブル平均後の流速ベクトルー風圧係数 分布を示す。図 7 同様に濃淡で渦度を示し、さらに同符号の渦度分
布を実線で囲った。符号は渦度の符号を示している。アンサンブル 平均後の両側面の風圧係数は、表 5 の最下段に示している。

図 11aより、 $\mathrm{L}$ 面の負圧が強いときには $\mathrm{L}$ 面側からの剥離せん断 層が背面直近で巻き込み、背圧も $\mathrm{L}$ 面から $\mathrm{R}$ 面に向かうにしたがっ て圧力回復している。このとき $\mathrm{R}$ 面側からの剥離せん断層は $\mathrm{L}$ 面側 からの剥離せん断層を取り囲むように現れている。図 $11 \mathrm{~b}$ には、 $\mathrm{R}$ 面の負圧が強いときを示したが、図 11a とは左右逆転して同様の結 果となっている。

$\mathrm{X}$ 軸上で見た、図 11a, 図 11b の流速ベクトルの V 成分の値を図 12 に示す。同様に、図 $11 \mathrm{c}$, 図 $11 \mathrm{~d}$ の流速ベクトルのU成分の值を 図 13 に示す。図 12 では X/D=2〜3 にかけての広い範囲で、a)では 負方向、b)では正方向に強い流れが生じている。 $\mathrm{X} / \mathrm{D}=3 \sim 3.5$ 前後で $\mathrm{V}$ の符号が逆転し、X/D=3.5〜 4 にかけては再び絶対值が大きくなっ ていることから、この図からも後流域で交番的な渦が現れているこ とが解る。

図 $11 \mathrm{c}$ では $\mathrm{L}$ 面， $\mathrm{R}$ 面とも負圧が強いが、このとき両側からの剥 離せん断層は背面からあまり離れていないところで勢力が拮抗して いる。このとき $C_{b}=-0.86$ となっている。図 13 の)より後方淀み点 は X/D=2.5 である。図 11d は L 面, R 面とも負圧が弱いときを示し ている。両側から剥㒕したせん断層が背面近傍に回り込まずに後流 域が長くなっている。模型背面付近の渦度の絶对值は小さく、 $\mathrm{C}_{b}=-0.62$ である。このときの後方淀み点は、図 13 の)より $\mathrm{X} / \mathrm{D}=4$ 付近である。

図 $11 \mathrm{c}$, 図 $11 \mathrm{~d}$ は共に左右対称に近い剥離せん断層の様子である。 図 11c は、図10のc)からカルマン渦が交互に形成される間の状態で 


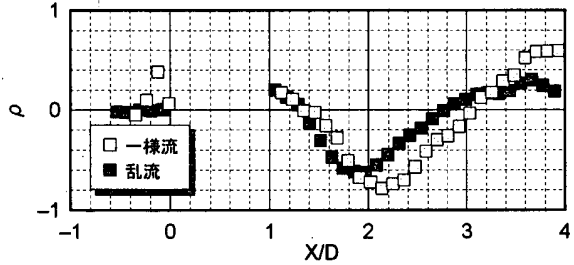

図 18a V 成分と揚力の相関係数（角柱）

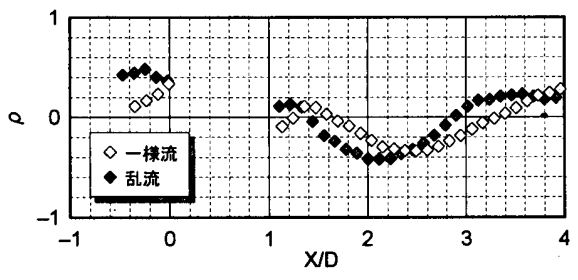

図 18b V 成分と揚力の相関係数（隅切）

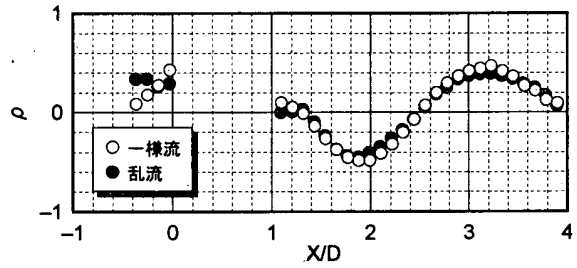

図 18c V 成分と揚力の相関係数（円柱）
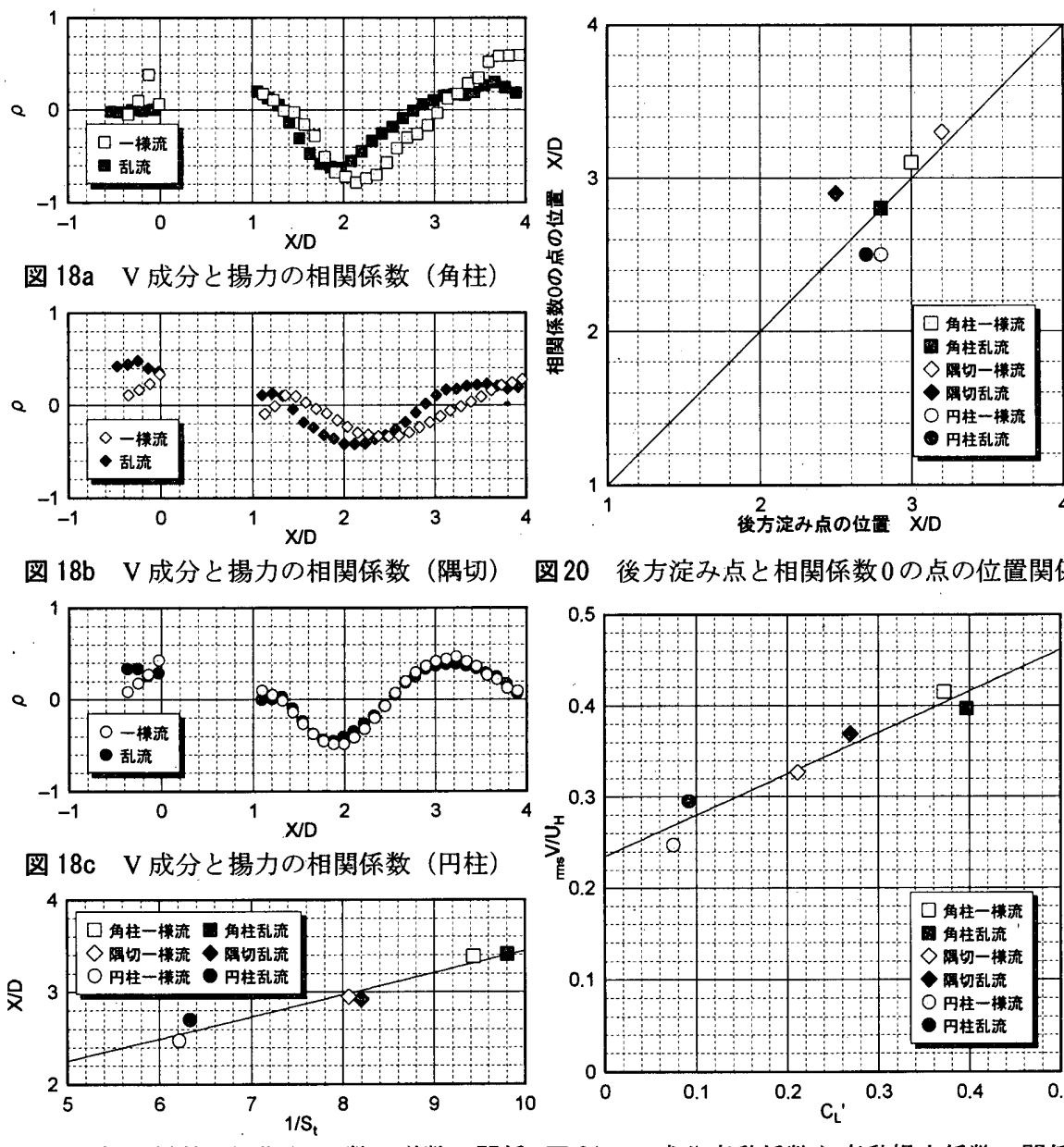

図 20 後方淀み点と相関係数 0 の点の位置関釈
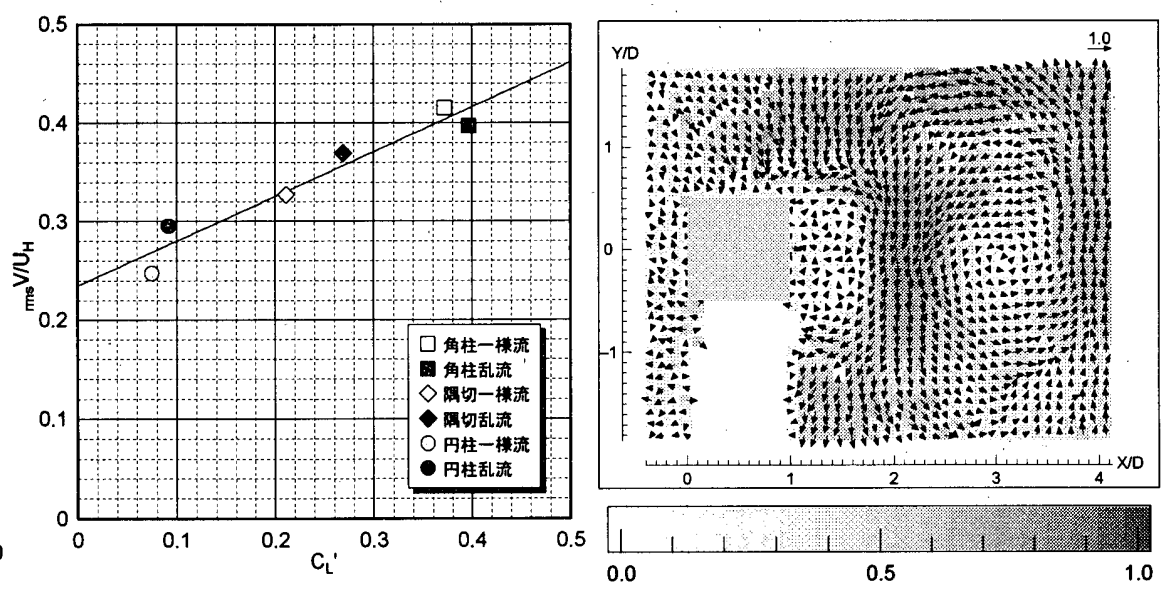

図 23 揚力と正の相関が最も強くなる方向
あると考えることができる。しかし、溝田ら゙2が示した二次元角柱ま わりの非定常流線図では位相角 $30^{\circ}$ に近似している。一方図 $11 \mathrm{~d}$ は、 溝田ら2)の示したカルマン渦の変動過程に現れていない。これは図 10 のd)からも明らかなように、明瞭なカルマン渦が形成されていな い状態と考えられる。野津ら ${ }^{33}$ は $\mathrm{Re}=3 \times 10^{2} \sim 1 \times 10^{3}$ の範囲で行った 三次元角柱の流体計算によって、アスペクト比が大きく Re 数が大 きいほど、角柱上面の自由端から剥㒕した流れが角柱背面に近づく ように下降する強いダウンウォッシュが発生し、それによって角柱 の背面に近い上層ではカルマン渦が破壊されるとしている。二次元 柱においても、西村 ${ }^{34)}$ は揚力変動に不規則なビート現象が存在ずる ことを示している。このようなダウンウォッシュやビート現象によ って、カルマン渦の不明瞭な状態が存在すると考えられる。

図 7a, 図 11c, 図 11d から、後方淀点と背圧係数, 抗力係数の 関係を図 14 に示す。後方淀み点が背面に近くなるにつれ、背面の負 圧が強くなり、抗力も大きくなっている。参考までに、溝田らりによ る二次元角柱の結果も示すが、同じ時間平均を比較しても、その值 は大きく異なっている。

\section{4 流れと空気力の相関 \\ 1) 相関係数の分布}

流れと空気力の関係を調べるために、流速ベクトルと風力係数(風 圧係数) の相関係数を求めた。PIV の全測定点 1280 点について、流 速ベクトルの $\mathrm{U}$ 成分, $\mathrm{V}$ 成分, 絶対值 $\mathrm{R}$ と、風力係数の抗力 $\mathrm{C}_{\mathrm{D}}$, 揚力 $\mathrm{C}_{\mathrm{L}}$, 背圧 $\mathrm{C}_{\mathrm{b}}$ の、計 9 つの相関係数 $\rho$ を求めた。相関を求めた
データ数は、流れと風圧の同時刻の記録数分であるので、表 4 の通 りである。このデータ数の範囲で一定の傾向が得られたため、検討 を加える。

図 15 に相関係数の絶対値の平均值 avg $\rho \mid$ と相関係数の標準偏差 $\mathrm{ms}$ $\rho$ を示す。図中、同一の 6 つの印は、それぞれ 6 ケースの実験を示 している。また横軸上と縦軸上にあるプロットは、6 ケースの実験 の平均值を示している。V 成分一揚力の相関は、6 ケースの平均で、 $\operatorname{avg}|\rho|, \operatorname{mss} \rho$ とも 9 つの相関の中で卓越して大きい值を示している。 これは V 成分一揚力の相関が強く、また相関係数の值が空間的に大 きく変動していることを示している。一方同じV成分でも、背圧や 抗力との相関は非常に弱い。V 成分一揚力の相関の次に ${ }_{\text {avg }} \rho \mid$ |が大き いのは、U 成分一抗力や絶対值 $\mathrm{R}$ 一抗力であるが、これは風が強い 瞬間には風方向の力が強いということを示している。 $\mathrm{rms} \rho$ が 2 番目 に大きいのは U 成分一揚力の相関で、この関係も相関係数の空間変 動が大きいことが判る。実験ケースごとの比較では、揚力に関係す る值は avg $\rho \mid, \mathrm{ms} \rho$ とも角柱一様流の值が卓越して大きい。これは剥 離点や気流の性状から、カルマン渦が形成されやすい条件が重なっ ているためと考えられる。そこで実験結果を明確に捉えやすい角柱 一様流について、空間変動が大きいとの結果が得られた U 成分一揚 力と V 成分一揚力の、相関係数の空間的な分布を示す。

\section{2）U成分と揚力の相関}

図 16 に角柱一様流における流速ベクトルのU 成分.と揚力の相関 係数分布を示す。模型の後縁付近に強い相関があり、その後方には 
後縁付近とは逆符号の相関の強い領域がある。正方向揚力の大きい 図 11a と比較してみると（図 11a は表 5 の a) 列で示したような、 $\mathrm{C}_{\mathrm{sL}}$ の負圧が強い 5 記録から成るが、 $\mathrm{C}_{\mathrm{L}}$ が大きい 5 記録を抽出して も同一の 5 記録であったため、ここでは揚力が大きい記録として扱 う）、L 面側の後縁では U 成分が大きく、R 面側の後縁では、U 成 分の絶対值が小さいか逆符号が見られる。またそれら後方の、相関 係数の符号が逆転する領域においても、図 11a の流速ベクトル分布 と対応していることが確認できる。

\section{3） V 成分と揚力の相関}

図 17 に角柱一様流における流速べクトルの V 成分と揚力の相関 係数分布を示す。濃い縦縞が現れており、V 成分と揚力の間には、 一見して強い相関があることが判る。V 成分と揚力の相関は、背面 に最も近いところに小さな正の相関を持つ領域があり、後方に行く に従い負の相関が強い領域、さらに正の相関が強い領域と、正負の 相関の強い領域が交互に存在している。図 12 の a) と比較すると、相 関俰数の絶対值が大きい領域では、その符号と等しい方向の V 成分 の強い流れが確認できる。

角柱一様流以外の 5 ケースについても図 17 に相当する図を描き、 $\mathrm{X}$ 軸上で見た V 成分と揚力の相関係数を図 18a〜18c に示す。形状 によって相関俰数の大小はあるものの、いずれも正弦関数のような 值を示している。相関係数の振幅は角柱が最も大きく、続いて円柱、 隅切の順であり、角柱の隅を切ることによる剥離せん断層制御の効 果が現れている。

相関係数が極值を取る位置から得られる波長（極小值と極大値の 距離の 2 倍）と、St 数の逆数の関係を図 19 に示す。それぞれの実 験ケースがほぼ直線上に位置することから、後流の相関係数が極大 または極小となる周期は、渦の放出周期と密接な関係があると考え られる。

相関係数が負から正に符号が変わる位置のX座標と後方淀み点の $\mathrm{X}$ 座標の関係を図 20 に示す。ほほ同じ位置となっていることから、 平均的に U 成分が 0 となる後方淀み点においては、V 成分の揚力と の相関も無相関に近いと言える。

図 15 で見たように、V 成分と揚力の相関は他の相関に比べて強い 相関関係にあることから、その変動係数と変動揚力係数の相関も強 くなっていると考えられる。図 21 に V 成分の変動係数 $\mathrm{rms} / \mathrm{U}_{\mathrm{H}}$ と変 動揚力係数 $\mathrm{C}_{\mathrm{L}}{ }^{\prime}$ の関係を示す。ここで選択する V 成分の変動係数は、 図 18a〜18ck示した、X 軸上で揚力との相関が最も強い（負の相関 係数が最大)点とした。それぞれの実験ケースはほぼ直線上に並び、 揚力変動の大きさは後流域のV成分の変動に関係が深いと考えられ る。

\section{4）揚カとの相関が最大となる方向}

2)，3)では揚力との相関を $U$ 成分， $V$ 成分とで検討した。しかし 例えば揚力との相関が、U 成分は正の相関が強く $\mathrm{V}$ 成分は負の相関 が強い点があるとすると、この点で最も強い相関を持つ方向は X 軸 正方向と $\mathrm{Y}$ 軸負方向の間の方向にあると考えられる。そこで図 22 のような方法を用いて、各測定点における揚力との正の相関が最も 強くなる方向 $\theta$ と、そのときの相関係数 $\mathrm{r}$ を求めた。図 23 はこの $\mathrm{r}$, $\theta$ を用いて、長さ $\mathrm{r}$, 偏角 $\theta$ のべクトルを描いた図を示している。 また相関係数 $\mathrm{r}$ は色の濃淡でも示した。この図は、ベクトルの向き を反転させれば、揚力と負の相関が最も強い方を向を表すことになる。
図 23 から、 $\mathrm{X} / \mathrm{D}=3.0, \mathrm{Y} / \mathrm{D}=0$ の後方淀み点付近は、流れのどの方 向成分とも無相関に近いと言える。後方淀み点を中心に、同心円上 に相関が強くなる。図 17 と同様に、 $\mathrm{X} / \mathrm{D}=1.0 \sim 1.6 、 \mathrm{Y} / \mathrm{D}=0$ 付近では 相関が弱く、 $\mathrm{X} / \mathrm{D}=1.8 \sim 2.5 、 \mathrm{Y} / \mathrm{D}=0$ 付近で揚力と反対方向の $\mathrm{V}$ 成分 との相関が強い。また角柱の側面後方に当たる $\mathrm{X} / \mathrm{D}=0.9 \sim 1.8, \mathrm{Y} / \mathrm{D}=$ 土0.9〜周辺は後流域から外れ、流れの大部分をU 成分が占めるが、 揚力との関係においては V 成分が大きく関係している。これらの領 域のベクトルは揚力と逆方向を示している。

図 23 と共に図 11a を参照すると、L面側の剥離せん断層が小さく 背面直近で巻き込んでいることから、図 11a の L 面付近においては $\mathrm{V}$ 成分の值が小さい。 $\mathrm{R}$ 面側は、巻き込んだ $\mathrm{L}$ 面側の剥離せん断層 に押される形で剥離せん断層が離れ、その結果 $\mathrm{V}$ 成分の值が小さく なっている。この図 11a は正方向の揚力を生じていることから、剥 離せん断層の側面からの距離が近い方向に揚力が生じることになる。

\section{4. まとめ}

PIV を用いた流れの測定と多点風圧測定装置を用いた風圧の測定 を同時に行い、細長い三次元柱周りの流れとこの柱に作用する空気 力の関保について述べた。

本研究で用いた、現在実用化されている PIV は、撮影時の光量や コンピュータの処理能力の点から、十分な大きさの撮影領域と時間 分解能を確保することができないという欠点がある。また粒子画像 の解析ができずに、エラーを出す点もある。しかし、可視化技術全 般に言える測定領域の情報を同時に得られる点や、計測器の挿入に 比べ流れを乱すことがない点、空間分解能が高いといった利点があ り、応用範囲の広い技術と言える。本研究では、PIV を物体周りの 流れの構造と空気力の関係の解明に応用した。以下に本研究により 得られた知見を示す。

1.PIV のサンプリングでは、十分な数の瞬間流速ベクトルを重ね合 わせることにより、対称な平均流れの様子を捉えた。また平均渦 度の分布より：物体の角が滑らかなほど後流幅が狭くなることを 確認した。

2. 瞬間流れと瞬間風圧の同時刻の記録から、側面風圧に着目した条 件抽出を行った。その結果、側面風圧の条件によって、剥離せん 断層が交番的に巻き込んでいる様子や、左右対称の剥離せん断層 の様子を捉えた。また後方淀み点が背面に近いほど、背面の負圧 が強くなる傾向を確認した。

3. 流速ベクトルと風力倸数の相関を求めた結果、流速ベクトルの V 成分と揚力の相関が最も強く、また相関係数の空間変動も最大で あった。

4. 流速ベクトルの V 成分と揚力の相関係数は、後流域において空間 的に正弦関数のような変動がある。この空間変動の周期は St 数の 逆数と強い相関があり、渦放出に関連していると考えられる。

5. 変動揚力保数は、揚力との相関が強い点における流速ベクトルの $\mathrm{V}$ 成分の変動係数との相関が強い。また揚力との相関が最も弱い 点は、後方淀み点にほぼ一致する。

6. 流れと揚力との関係においては、後流内はもちろん後流外におい ても、流速べクトルの V 成分の関わりが大きく、剥離せん断層が 近い方の側面の方向に揚力が生じる。 
本研究は、筑波建築研究機関協議会(BRIC)の「数值シミュレーシ ヨン技術を応用した建築物の耐風性能設計」に関する共同研究によ るものである。

\section{謝辞}

本研究を行うにあたり、財団法人つくば科学万博記念財団より補 助金の交付を受けました。ここに感謝の意を表します。また査読委 員には非常に有益なご意見をいただきました。最後に記して謝意を 表します。

\section{参考文献}

1) 渾田武人, 岡島厚 : 角柱まわりの時間平均流れに関する実験的研究, 土木 学会論文報告集, 第 312 号, pp.39-47, 1981.8

2）满田武人, 岡島厚 : 角柱まわりの非定常流れに関する実験的研究, 土木学 会論文報告集，第 312 号, pp.49-57, 1981.8

3) 田村哲郎, 伊藤嘉晃：角柱まわりの流扎と空力特性の辺長比による変化 日本建築学会構造系論文集, 第 486 号, pp.153-162, 1996.8

4）西村宏昭, 谷池義人：2 次元静止円柱に作用する変動風圧性状, 第 15 回 風工学シンポジウム論文集, pp.269-274, 1998.12

5）西村宏昭, 谷池義人: 二次元正方形角柱の変動風圧特性, 日本建築学会構 造系論文集，第 533 号，pp.37-43，2000.7

6) 西村宏昭, 谷池義人: 二次元静止正方形角柱の変動空気力特性, 第 16 回 風工学シンポジウム論文集, pp.255-260, 2000.11

7) 西村宏昭, 谷池義人: 二次元長方形角柱の変動風圧特性, 日本建築学会構 造系論文集，第 538 号, pp.49-55, 2000.12

8）野田博，中山昭彦: 一様流中ならびに一様乱流中における角柱の風圧特性 に関寸る実験的研究，土木学会論文集，第 668 号, I-54, pp.117-130, 2001.1

9) 田村哲郎, 宮城哲矢: 正方形角柱の空力特性に与える隅角部形状妏果の物 理機構に関する系統的研究, 日本建築学会構造系論文集, 第 514 号, pp.51-58, 1998.12

10) 田村哲郎, 宮城哲矢 : 正方形角柱の隅角部形状に基づく空力低減機構に関 する研究一風圧力特性による研究一, 日本建築学会構造系論文集, 第 521 号, pp.17-24, 1999.7

11) 岡島厚 : 種々な断面辺長比の矩形断面柱周りの流れ, 日本風工学会誌, 第 17 号, pp.1-19, 1983.9

12）西村宏昭, 谷池義人: 2 次元静止円柱の変動風力発生機構, 日本風工学会 誌, No.74, pp.47-58, 1998.1

13) 谷池義人, 奥田泰雄 : 3 次元角柱周りの渦構造（その1）渦放出の強さ, 第 11 回風工学シンポジウム論文集, pp.119-124, 1990.12

14) 奥田泰雄, 谷池義人： 3 次元角柱周りの洞粠造 (その 2$)$. 側面上に形成さ れる渦，第 11 回風工学シンポジウム論文集，pp.125-130，1990.12

15) 奥田泰雄, 谷池義人 : 3 次元角柱側面上に形成される逆円錐状渦, 第 12 回風工学シンポジウム論文集, pp.167-172, 1992.12

16) Okuda, Y. and Taniike, Y.: Flow Visualization Around a Three Dimensional
Square Prism; 日本風工学会誌, 第 37 号, pp.25-132, 1988.10

17) 河村進一, 久保喜延，山口栄輝：前縁隅角部に曲率を有する断面の空力特 性に関する風洞実験および数值流体解析, 土木学会論文集, 第 619 号1-47, pp.67-74, 1999.4

18) 小林敏雄, 岡本孝司，佐賀徹雄 : Particle Image Velocimetry の展開, 可視 化情報, Vol.20, No.77, pp.1-6, 2000.4

19) 可視化情報学会 : PIV ハンドブック，森北出版, 2002.7

20) 平工良三, 鈴木敏夫 : 高速度ビデオカメラを用いた連続画像データ処理に よる三次元流速測定法の開発, 可視化情報, Vol.19, Suppl.No.2, pp.149-152, 1999

21) 西野耕一:3 次元 PIV の実用化に向けて, 可視化情報, Vol.20, No.77,pp.7-13, 2000.4

22) M.ラッフェル, C.E.ヴィラート, J.コンペンハンス : PIV の基礎と応用一 粒子画像流速測定法一，シュプリンガー・フェアラーク東京, 2000.6

23) 大橋征幹, 登梛正夫, 佐々木康人, 伊藤真二, 吉村直樹, 長井信夫, 渡壁 守正, 奥田泰雄, 岡田恒 : 塔状構造物周りの平均流れ（その 2) PIVによ る実験と数値計算の比較, 日本建築学会大会学術講演梗概集, B-1, pp.111-112, 2001.9

24) 奥田泰雄, 大橋征幹, 佐々木康人, 伊藤真二, 松山哲雄 : 物体まわりの流 れと風圧の同時計測-PIV と多点同時計測, 京都大学防災研究所研究集会, 最新の風洞実験法に関する比較研究, pp.35-36, 2001.12

25) 喜々津仁密, 奥田泰雄, 伊藤真二, 大橋征幹, 佐々木康人, 松山哲雄 : 建 築物周りの流れと建築物に作用する風圧との同時測定（その1）立方体, 日本建築学会大会学術詇演梗概集, B-1, pp.153-154, 2002.8

26)吉川清峰, 奥田泰雄, 伊藤真二, 大橋征幹, 佐々木康人, 中村豊 : 建築物 周りの流れと建築物に作用する風圧との同時測定（その2）角柱，日本建 築学会大会学術講演梗概集, B-1, pp.155-156, 2002.8

27) 伊藤真二, 奥田泰雄, 大橋征幹, 佐々木康人, 松山梊雄, 喜々津仁密 : 立 方体周りの流れと風圧の同時測定一屋根面の瞬間的な再付着について一, 第 17 回風工学シンポジウム論文集, pp.267-272, 2002.12

28) 吉川清峰, 奥田泰雄, 伊藤真二, 大橋征幹, 佐々木康人:アスペクト比の 大きい柱周りの風直角方向の流れと場力の相関, 日本風工学会誌, 第 95 号, pp.141-142，2003.4

29) 吉川清峰, 奥田泰雄, 伊藤真二, 大橋征幹; 佐々木康人 : アスペクト比の 大きい柱周りの流札と空気力の相関, 日本建築学会大会学術講演梗概集, B-1，2003.9（投稿中）

30) 田村幸雄 : 構造基本断面の空力特性（その 3 ） 8.3 次元円筒の空気力, 日 本風工学会誌，第 39 号, pp.36-47, 1989.4

31) 富岡清, 山下真佐美：技 1 DANTEC 社のリアルタイム PIV システ ム”FlowMap"を用いた測定の最適化と統計べクトル処理，可視化情報， Vol.18, Suppl.No.1, pp.233-236, 1998.7

32) Laneville, A., Gartshore, I. S. and Parkinson, G. V.: An explanation of some effects of turbulence on bluff bodies, Proc. Fourth International Conference on Wind Effects on Building and Structures, Heathrow, 1975

33) 野津剛, 田村哲郎: 高精度 ・保存的流体計算法の耐風問題一の適用性につ いて (その 2) 地面上の 3 次元角柱まわりの瀜棈造と空力特性, 日本建築 学会構造系論文集, 第 503 号, pp.37-43, 1998.1

34) 西村宏昭:Bluff Body の空力特性に関する基脴的研究, 京都大学博士論文, 2001.5

(2003年 2 月 5 日原稿受理， 2003 年 8 月 19 日採用決定） 